\title{
Grazing impacts on litter and soil organic matter in mixed prairie and fescue grassland ecosystems of Alberta
}

\author{
M.A. NAETH, A.W. BAILEY, D.J. PLUTH, D.S. CHANASYK, AND R.T. HARDIN
}

\begin{abstract}
Impacts of long-term cattle grazing on litter and soil organic matter were assessed in mixed prairie, parkland fescue, and foothills fescue grasslands of Alberta, Canada. Grazing regimes were of light to very heavy intensities, grazed early, late, and continuously during the growing season. Litter and soil organic matter were sampled in $0.1-\mathrm{m}^{2}$ quadrats and removed as live vegetation, standing litter, fallen litter, and soil organic matter. Litter and organic matter samples were air dried and sorted by size using sieves and an automatic sieve shaker. Organic carbon content was determined by thermal oxidation. Ground cover was determined using point frames, and heights of standing litter and fallen litter were measured.

Heavy intensity and/or early season grazing had greater negative impacts on litter and soil organic matter than did light intensity and/or late season grazing. Under the former regimes there were significant reductions in heights of standing and fallen litter, decreases in live vegetative cover and organic matter mass, and increases in bare ground. More large particle-sized organic matter, particularly standing litter, occurred in controls than in grazed treatments since it would not be removed or trampled by grazing animals. More medium and small particle-sized organic matter occurred in grazed treatments than in ungrazed controls since vegetation likely decomposed more rapidly when it was trampled and broken down as animals grazed.
\end{abstract}

Key Words: organic carbon, ground cover, Solonetzic soils, Chernozemic soils, rough fescue

In the Canadian Northern Great Plains, accumulated litter ranges from 0.28 to $1.24 \mathrm{~kg} \mathrm{~m}^{-2}$ in fescue grasslands (Johnston 1961 , Willms et al. 1986) and from 0.06 to $0.09 \mathrm{~kg} \mathrm{~m}^{-2}$ in mixed prairie (Smoliak 1965, Willms et al. 1986). Grazing reduces litter mass, with lowest values under very heavy grazing (Coupland et al. 1960, Johnston 1961, Johnston 1962, Johnston et al. 1971). Some researchers found grazing does not affect soil organic matter (Lodge 1954, Johnston et al. 1971, Dormaar et al. 1977). Others found heavy grazing reduces total carbon in Ah horizons in some grasslands (Smoliak et al. 1972, Dormaar et al. 1977) and increases it in other grasslands (Dormaar et al. 1984). Below ground dry matter can decrease under grazing (Coupland et al. 1960, Smoliak 1965) or increase (Johnston 1961, Smoliak et al. 1972), with the most significant changes occurring in the upper $15 \mathrm{~cm}$ of the soil profile.

Branson (1984) stated there may be a critical point in moist climates at which litter accumulation above $0.5 \mathrm{~kg} \mathrm{~m}^{-2}$ depresses plant yields. In Canadian mixed prairie, litter accumulation is not high enough to significantly reduce herbage productivity (Willms

\footnotetext{
Authors are research associate, Department of Soil Science; professor, Department of Plant Science; professor, Department of Soil Science; professor, Department of Soil Science; and professor, Department of Animal Science, University of Alberta, Edmonton, Alta., Canada, T6G 2E3. At the time of the research, the senior author was a Ph.D. graduate student, Department of Plant Science, University of Alberta.

The authors wish to acknowledge the financial support of NOVA Corporation of Alberta. K. Ostermann, V. Naeth, J. Scott, J. McGill, G. Hoppe, and D. White are thanked for their technical assistance. The Lethbridge Research Station of Agriculture Canada, the Eastern Irrigation District, and the University of Alberta are acknowledged for the use of their long-term grazing treatments.

Manuscript accepted 10 May 1990.
}

et al. 1986). In Canadian fescue grasslands, removal of standing dead and surface litter marginally increased yields and increased tiller density for 2 (Sinton 1980) and 3 (Willms et al. 1986) years after litter removal. There was no evidence these trends continued beyond 3 years. In most Northern Great Plains studies, litter accumulation does not generally exceed $0.27 \mathrm{~kg} \mathrm{~m}^{-2}$ and does not adversely affect range condition or productivity. From a hydrologic perspective, there is considerable uncertainty about amounts of litter and vegetative cover needed to prevent excessive runoff and erosion under the diverse topography and soil conditions of grasslands (Meeuwig 1970). Litter and soil organic matter increase soil aggregation, aggregate stability, and infiltration rate, and decrease raindrop impact, runoff, erosion, and soil surface evaporation (Tomanek 1969). They provide habitats for organisms and retain nutrients (Risser 1984). Thus for hydrologic benefit on most rangelands, management for litter accumulation may be as important as management for increasing live plant cover (Branson 1984).

Since litter and soil organic matter have numerous beneficial effects on grasslands, it is important to determine how they are affected by grazing. The major objective of this study was to determine how litter and soil organic matter were affected by season and intensity of grazing in Alberta mixed prairie and fescue grassland ecosystems. It was hypothesized that both season and intensity of grazing would affect amounts of soil organic matter and litter. It was also hypothesized that proportions of litter of different particle sizes would vary with season and intensity of grazing due to trampling and breakdown during grazing. Inherently, litter of different particle sizes would decompose at different rates, affecting soil organic matter mass. Therefore a second objective was to categorize litter and soil organic matter according to particle size and to quantify categories with grazing treatments. Previous studies in Alberta rangelands had not examined total litter or soil organic matter.

\section{Materials and Methods}

\section{Study Sites}

Three study sites representing major rangeland ecosystems of southern and central Alberta were selected. Each site had longterm grazing treatments, ungrazed controls, grass-dominated vegetation that had never been cultivated, and slopes of less than $2 \%$ (Naeth 1988).

The mixed prairie site was located near Brooks approximately $225 \mathrm{~km}$ east of Calgary $\left(51^{\circ} \mathrm{N}\right.$ and $\left.112^{\circ} \mathrm{W}\right)$. The area has a continental prairie climate and a semiarid moisture regime. Mean annual precipitation is $355 \mathrm{~mm}$. Mean annual temperature is $4^{\circ} \mathrm{C}$, with a July mean of $19^{\circ} \mathrm{C}$ and a January mean of $-14^{\circ} \mathrm{C}$. Elevation averages $745 \mathrm{~m}$ above sea level with slopes of less than $2 \%$. Soils are Brown Solodized Solonetz and Brown Solod (Natriboroll) developed on till (Kjearsgaard et al. 1982). Vegetation is of the Blue grama-Spear grass-Wheat grass (Bouteloua-Stipa-Agropyron) faciation, dominated by blue grama grass (Bouteloua gracilis Lag.), spear grass (Stipa comata Trin. \& Rupr.), and western and northern wheatgrasses (Agropyron smithii Rydb. and dasystachyum Hook.). Pasture sage (Artemisia frigida Willd.) and little club- 
moss (Selaginella densa Rydb.) are common forbs. A short grass disclimax dominated by blue grama is common as a result of heavy long-term grazing.

The parkland fescue site was located near Kinsella approximately $150 \mathrm{~km}$ southeast of Edmonton $\left(53^{\circ} \mathrm{N}\right.$ and $\left.111^{\circ} \mathrm{W}\right)$. The climate is dry subhumid. Mean annual precipitation is $422 \mathrm{~mm}$. Mean annual temperature is $2^{\circ} \mathrm{C}$, with a July mean of $17^{\circ} \mathrm{C}$ and a January mean of $-17^{\circ} \mathrm{C}$. Elevation averages $685 \mathrm{~m}$ above sea level with gently rolling to hilly topography (Howitt 1988). Grassland soils are dominated by Orthic Black Chernozems (Cryoboroll) developed on till. Vegetation consists of grass and shrub communities with aspen groves occurring at irregular intervals. Plains rough fescue (Festuca hallii Vasey Piper) (Pavlick and Looman 1984) dominates open undisturbed grasslands, and western porcupine grass (Stipa curtiseta Hitchc.) co-dominates on grazed areas. Forbs are a common component of the vegetation.

The foothills fescue grassland site was located near Stavely approximately $100 \mathrm{~km}$ south-southwest of Calgary $\left(50^{\circ} \mathrm{N}\right.$ and $114^{\circ} \mathrm{W}$ ). The climate is subhumid without marked deficiency of precipitation. Mean annual precipitation is $550 \mathrm{~mm}$. Mean annual temperature is $5^{\circ} \mathrm{C}$, with a July mean of $18^{\circ} \mathrm{C}$ and a January mean of $-10^{\circ} \mathrm{C}$. Elevation averages $1,350 \mathrm{~m}$ above sea level and topography is gently rolling to hilly. Soils are Orthic Black Chernozems (Haploboroll) developed on till (Johnston et al. 1971). Vegetation is of the fescue grassland association with rough fescue (Festuca campestris Rydb.) dominating in the undisturbed and lightly grazed areas. Parry's oat grass (Danthonia parryi Scribn.) and bluebunch fescue (Festuca idahoensis Elmer) are co-dominates in grazed areas. Under heavy grazing regimes, rough fescue is replaced by annual invaders and bluegrass (Poa L.) species.

\section{Grazing Treatments}

In mixed prairie, 3 grazing treatments were studied within a community pasture established in 1964: (1) early season grazing from May through July; (2) late season grazing from August through October; and (3) a control ungrazed since the late 1930s. The stocking rate was heavy at $0.9 \mathrm{AUM} \mathrm{ha}^{-1}$ (B. Shanks, personal communication, December 1984).

In parkland fescue, 5 grazing treatments established in 1973 on the University of Alberta ranch were studied: (1) light June grazing from 1 to 30 June at $1.5 \mathrm{AUM} \mathrm{ha}^{-1}$; (2) heavy June grazing from 1 to 30 June at $4.4 \mathrm{AUM} \mathrm{ha}{ }^{-1}$; (3) heavy autumn grazing from 15 September to 15 October at $4.4 \mathrm{AUM} \mathrm{ha}^{-1}$; (4) light autumn grazing from 15 September to 15 October at $1.5 \mathrm{AUM} \mathrm{ha}^{-1}$; and (5) a control ungrazed since 1942 (Bailey et al. 1987).

In foothills fescue, 5 grazing treatments established in 1949 on the Agriculture Canada Range Research Substation and grazed May through September were studied: (1) very heavy grazing at 4.8 AUM ha ${ }^{-1}$; (2) heavy grazing at 2.4 AUM ha ${ }^{-1}$; (3) moderate grazing at $1.6 \mathrm{AUM} \mathrm{ha}{ }^{-1}$; (4) light grazing at $1.2 \mathrm{AUM} \mathrm{ha}^{-1}$; and (5) a control comprised of permanent exclosures in each treatment (Johnston et al. 1971).

\section{Experimental Design and Statistical Analyses}

The experimental design within each site had a hierarchical arrangement of grazing treatment, sample area, and subsamples (Steel and Torrie 1980). Three 0.1-ha sample areas were randomly established within each treatment.

Statistical analyses were conducted using variation among the 0.1-ha sample areas as a measure of error for testing the significance of treatments. Data were tested for homogeneity of variance using Cochran and Bartlett-Box tests. The $W$ test was used to test data for normality of distribution (Shapiro and Wilk 1965). Analysis of variance was used to test for treatment effects. Data with significant $F$ values were further analyzed to separate the means using the Student-Newman-Keul(SNK) test at the 5\% probability level
(Steel and Torrie 1980).

In each year by treatment combination, variation among samples was not significantly different from subsamples and therefore, sample and subsample variation were pooled in further analyses. There were no significant differences within a treatment between study years so data from both years were pooled. Sources of variation in the final statistical analysis were treatments and error within treatments.

\section{Sampling and Analyses}

For this study, litter refers to all dead organic material not incorporated with mineral soil and occurring above soil mineral horizons. Soil organic matter refers to the organic fraction of soil (Canada Department of Agriculture 1979).

At each site, sampling was conducted in late August 1985 and 1986 using 10 randomly located $0.1-\mathrm{m}^{2}$ quadrats in each sample area ( 30 per treatment). Live vegetation, including dried tips of live plants, and standing litter were removed with clippers at ground level. Fallen litter was removed from the soil surface with hand rakes. Soil organic matter was lifted as a slab, after cutting down to a mineral soil horizon where color and textural changes were used to locate the bottom of the Ah horizon. Sampling depths ranged from 5 to $8 \mathrm{~cm}$ in mixed prairie (no difference in depth among treatments) and 10 to $15 \mathrm{~cm}$ in parkland fescue (no difference in depth among treatments) and foothills fescue (very heavy treatment shallower than other treatments).

Live vegetative material was oven dried at $65^{\circ} \mathrm{C}$ for 24 hours, then weighed. Litter and organic matter samples were air dried then sorted by size using sieves mounted on an automatic sieve shaker as modified from Coupland (1973). Five minutes of shaking was required to sort the samples without breaking down plant material. Sieves selected on the basis of laboratory trials had openings of $2.0,0.85$, and $0.212 \mathrm{~mm}(9,20$, and 65 mesh Tyler equivalents), with a bottom pan.

The litter and soil organic matter were separated into 6 categories: (1) standing litter collected in the field; (2) coarse litter remaining in the top sieve $(2 \mathrm{~mm})$ and recognizable as undecomposed plant parts; (3) medium litter that was partly decomposed and collected in the second sieve $(0.85 \mathrm{~mm})$; and (4) fine organic matter that was relatively decomposed and collected in the third sieve $(0.212 \mathrm{~mm})$; (5) very fine organic matter that was decomposed and collected in the bottom pan; and (6) roots visibily greater than 0.2 $\mathrm{mm}$ which were removed from the above samples. Categories 4 and 5 contained most smaller roots and root hairs. The above ground category comprised standing, coarse, and medium litter, and live vegetation. The below ground category comprised roots, and fine and very fine organic matter. Total organic matter included all above categories.

To measure organic matter in each category and to separate it from mineral matter included in the total weight, organic carbon content was determined by oxidation with a Leco Carbon Determinator. In each category, 5 subsamples from each 0.1 -ha area were analyzed (15 per treatment). Soil samples were ground to pass through a $0.15-\mathrm{mm}$ sieve. Soil carbonates in 10 samples from each study site were determined by acid neutralization to $\mathrm{pH} 8.2$ (Black 1965). Organic carbon was calculated by subtracting percent inorganic carbon from percent total carbon. Percent organic carbon was multiplied by 1.724 (organic matter is approximately $58 \%$ organic carbon) to determine percent organic matter in each category. This value was then multiplied by total mass of each category to give mass in the $0.1 \mathrm{~m}^{2}$ sample. Masses were then converted to specific mass $\left(\mathrm{kg} \mathrm{m}^{-2}\right)$.

In each 0.1-ha area, 10 randomly located 10-point transects were used to determine percent bare ground, live vegetation, and dead vegetation ( 300 points per treatment). Standing litter, fallen litter, and standing litter heights $(\mathrm{cm})$ of each major plant species or 
Table 1. Percent ground cover (bare ground, live vegetation, litter) in mixed prairie, parkland fescue, and foothills fescue grasslands.

\begin{tabular}{|c|c|c|c|c|}
\hline \multirow[b]{2}{*}{ Site } & \multirow[b]{2}{*}{$\begin{array}{l}\text { Grazing } \\
\text { treatment }\end{array}$} & \multicolumn{3}{|c|}{ Ground Cover Category } \\
\hline & & $\begin{array}{c}\text { Bare } \\
\text { ground }\end{array}$ & $\begin{array}{c}\text { Live } \\
\text { vegetation }\end{array}$ & Litter \\
\hline $\begin{array}{l}\text { Mixed } \\
\text { Prairie }\end{array}$ & $\begin{array}{l}\text { Early Season } \\
\text { Late Season } \\
\text { Ungrazed Control }\end{array}$ & $\begin{array}{l}7.0 \mathrm{a} \\
4.0 \mathrm{ab} \\
1.5 \mathrm{~b}\end{array}$ & $\begin{array}{l}12.0 \mathrm{a} \\
15.5 \mathrm{a} \\
17.5 \mathrm{a}\end{array}$ & $\begin{array}{l}81.0 \mathrm{a} \\
80.5 \mathrm{a} \\
81.0 \mathrm{a}\end{array}$ \\
\hline $\begin{array}{l}\text { Parkland } \\
\text { Fescue }\end{array}$ & $\begin{array}{l}\text { Light June } \\
\text { Heavy June } \\
\text { Heavy Autumn } \\
\text { Light Autumn } \\
\text { Ungrazed Control }\end{array}$ & $\begin{array}{l}0.0 \mathrm{~b} \\
2.0 \mathrm{a} \\
0.5 \mathrm{~b} \\
0.0 \mathrm{~b} \\
0.0 \mathrm{~b}\end{array}$ & $\begin{array}{l}35.5 \mathrm{a} \\
31.5 \mathrm{a} \\
36.0 \mathrm{a} \\
38.5 \mathrm{a} \\
39.5 \mathrm{a}\end{array}$ & $\begin{array}{l}64.5 \mathrm{a} \\
66.5 \mathrm{a} \\
63.5 \mathrm{a} \\
61.5 \mathrm{a} \\
60.5 \mathrm{a}\end{array}$ \\
\hline $\begin{array}{l}\text { Foothills } \\
\text { Fescue }\end{array}$ & $\begin{array}{l}\text { Very Heavy } \\
\text { Heavy } \\
\text { Moderate } \\
\text { Light } \\
\text { Ungrazed Control }\end{array}$ & $\begin{array}{r}14.5 \mathrm{a} \\
10.5 \mathrm{~b} \\
1.0 \mathrm{c} \\
0.5 \mathrm{c} \\
0.0 \mathrm{c}\end{array}$ & $\begin{array}{l}21.0 \mathrm{~b} \\
22.0 \mathrm{~b} \\
30.5 \mathrm{a} \\
30.0 \mathrm{a} \\
12.3 \mathrm{c}\end{array}$ & $\begin{array}{l}64.5 b \\
67.5 b \\
68.5 b \\
69.5 b \\
87.7 a\end{array}$ \\
\hline
\end{tabular}

Within ground cover category means with the same letters are not significantly different $(P<0.05)$

group were measured at 30 randomly located points in each 0.1 -ha area (90 per treatment).

\section{Results}

\section{Mixed Prairie}

Live vegetation and litter components of ground cover were not affected by grazing (Table 1). Grazing increased bare ground 2.7 to 4.7 times, with early season grazing being more detrimental than late season grazing. Fallen litter height was 6.4 times greater in the control than in grazed treatments and standing litter was 1.4 times greater (Table 2).

Organic carbon was higher in litter categories than in soil organic matter categories (Table 3). Season of grazing affected organic carbon with early season grazing reducing values in roots and standing litter but increasing it in coarse and medium litter. Grazing treatment had no effect on organic carbon in soil organic

Table 2. Height (cm) of fallen and standing litter in mixed prairie, parkland fescue, and foothills fescue grasslands.

\begin{tabular}{llcc}
\hline Site & Grazing treatment & $\begin{array}{c}\text { Fallen } \\
\text { litter }\end{array}$ & $\begin{array}{c}\text { Standing } \\
\text { litter }\end{array}$ \\
\hline Mixed & Early Season & $0.5 \mathrm{~b}$ & $15.7 \mathrm{~b}$ \\
Prairie & Late Season & $0.5 \mathrm{~b}$ & $16.1 \mathrm{~b}$ \\
& Ungrazed Control & $3.2 \mathrm{a}$ & $21.3 \mathrm{a}$ \\
& & \\
\hline & Light June & $2.8 \mathrm{~b}$ & $30.7 \mathrm{c}$ \\
& Heavy June & $1.3 \mathrm{~b}$ & $29.6 \mathrm{c}$ \\
Parkland & Heavy Autumn & $1.9 \mathrm{~b}$ & $25.9 \mathrm{c}$ \\
Fescue & Light Autumn & $3.8 \mathrm{~b}$ & $37.3 \mathrm{~b}$ \\
& Ungrazed Control & $14.6 \mathrm{a}$ & $53.9 \mathrm{a}$ \\
& & & \\
\hline & & & \\
& & $0.2 \mathrm{e}$ & $36.4 \mathrm{~d}$ \\
Foothills & Very Heavy & $2.2 \mathrm{~d}$ & $48.9 \mathrm{c}$ \\
Fescue & Heavy & $4.9 \mathrm{c}$ & $55.0 \mathrm{~b}$ \\
& Moderate & $8.5 \mathrm{~b}$ & $57.3 \mathrm{ab}$ \\
& Light & $13.4 \mathrm{a}$ & $59.6 \mathrm{a}$ \\
\hline
\end{tabular}

Within litter category means with the same letters are not significantly different $(P<0.05)$. (a) Mixed Prairie

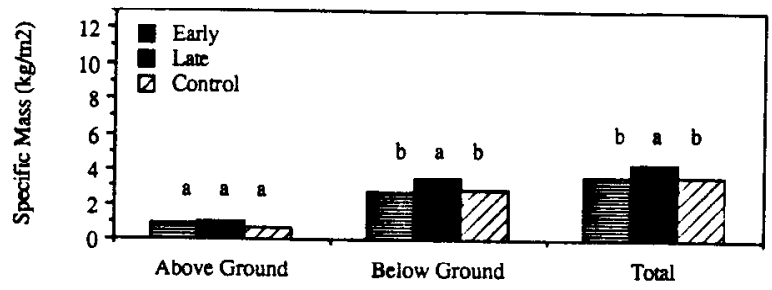

(b) Parkland Fescue

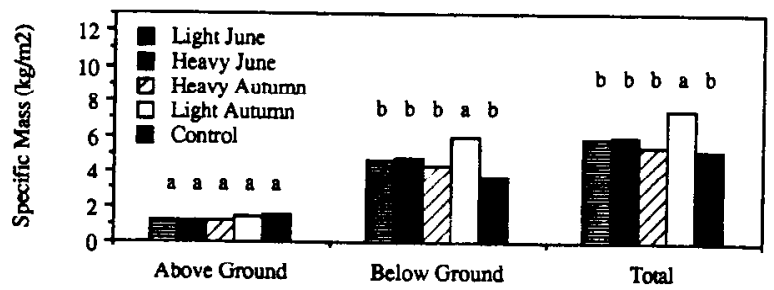

(c) Foothills Fescue

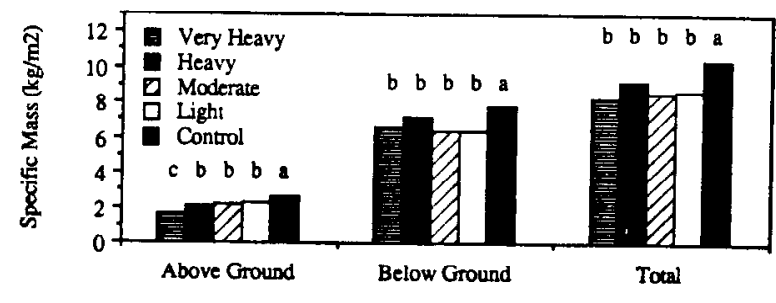

Liner And Organic Mater Caregory

Fig. 1. Specific mass of above-ground, below-ground, and total litter and organic matter in (a) mixed prairie, (b) parkland fescue, and (c) foothills fescue grasslands. Within category means with the same letters are not significantly different $(P<0.05)$.

matter. Above ground litter mass was not affected by grazing; below ground organic matter and total masses were highest under late season grazing (Fig. 1). Total mass was distributed approximately $75 \%$ below ground and $25 \%$ above ground. Greatest masses were in fine and very fine categories. Grazing did not have a significant effect on mass of standing litter, coarse litter, or very fine organic matter. Grazing increased medium litter and roots, and decreased live vegetation. Highest fine organic matter was under late season grazing.

\section{Parkland Fescue Grassland}

I ive vegetation and litter components of ground cover were not affected by grazing (Table 1). Bare ground increased only under heavy intensity grazing, particularly if grazed in June. Standing litter was 1.5 to 2.0 times higher and fallen litter was 4.0 to 11.0 times higher in ungrazed controls than in grazed treatments. Standing litter was higher under light autumn grazing than under any other grazed treatment (Table 2).

Organic carbon in roots and coarse litter was not affected by grazing but in standing litter it was highest in control and heavy June treatments and lowest in the heavy autumn treatment (Table 3). Organic carbon in medium litter, fine and very fine organic matter was lowest in the control, being 1.4 to 1.9 times higher in grazed treatments. Total organic matter was comprised of approximately two-thirds below ground and one-third above ground components (Fig. 1). Above ground mass was not affected by grazing. Below ground and total masses were highest in the light autumn treatment. Grazing decreased masses of standing and coarse litter and increased those of medium and very fine organic matter (Fig. 2). The highest fine organic matter mass was under 
Table 3. Organic carbon (\%) in litter and soil organic matter categories in mixed prairie, parkland fescue, and foothills fescue grasslands.

\begin{tabular}{|c|c|c|c|c|c|c|c|}
\hline \multirow[b]{2}{*}{ Site } & \multirow[b]{2}{*}{$\begin{array}{l}\text { Grazing } \\
\text { treatment }\end{array}$} & \multicolumn{6}{|c|}{ Litter and Organic Matter Category } \\
\hline & & Roots & $\begin{array}{c}\text { Standing } \\
\text { litter }\end{array}$ & $\begin{array}{c}\text { Coarse } \\
\text { litter }\end{array}$ & $\begin{array}{l}\text { Medium } \\
\text { litter }\end{array}$ & $\begin{array}{l}\text { Fine } \\
\text { organic } \\
\text { matter }\end{array}$ & $\begin{array}{c}\text { Very fine } \\
\text { organic } \\
\text { matter }\end{array}$ \\
\hline $\begin{array}{l}\text { Mixed } \\
\text { Prairie }\end{array}$ & $\begin{array}{l}\text { Early Season } \\
\text { Late Season } \\
\text { Ungrazed Control }\end{array}$ & $\begin{array}{l}22.0 \mathrm{~b} \\
28.0 \mathrm{a} \\
25.0 \mathrm{ab}\end{array}$ & $\begin{array}{c}23.2 \mathrm{~b} \\
29.1 \mathrm{a} \\
25.5 \mathrm{ab}\end{array}$ & $\begin{array}{l}31.4 \mathrm{a} \\
30.0 \mathrm{ab} \\
27.0 \mathrm{~b}\end{array}$ & $\begin{array}{r}14.4 \mathrm{a} \\
11.3 \mathrm{~b} \\
6.2 \mathrm{c}\end{array}$ & $\begin{array}{l}6.0 \mathrm{a} \\
6.0 \mathrm{a} \\
4.6 \mathrm{a}\end{array}$ & $\begin{array}{l}3.9 \mathrm{a} \\
4.3 \mathrm{a} \\
3.6 \mathrm{a}\end{array}$ \\
\hline $\begin{array}{l}\text { Parkland } \\
\text { Fescue }\end{array}$ & $\begin{array}{l}\text { Light June } \\
\text { Heavy June } \\
\text { Heavy Autumn } \\
\text { Light Autumn } \\
\text { Ungrazed Control }\end{array}$ & $\begin{array}{l}33.2 \mathrm{a} \\
34.8 \mathrm{a} \\
30.0 \mathrm{a} \\
31.3 \mathrm{a} \\
27.6 \mathrm{a}\end{array}$ & $\begin{array}{l}31.8 \mathrm{~b} \\
34.6 \mathrm{a} \\
29.7 \mathrm{c} \\
31.7 \mathrm{~b} \\
35.1 \mathrm{a}\end{array}$ & $\begin{array}{l}26.3 \mathrm{a} \\
28.8 \mathrm{a} \\
25.9 \mathrm{a} \\
29.3 \mathrm{a} \\
27.2 \mathrm{a}\end{array}$ & $\begin{array}{r}8.8 \mathrm{a} \\
8.8 \mathrm{a} \\
10.3 \mathrm{a} \\
10.6 \mathrm{a} \\
5.5 \mathrm{~b}\end{array}$ & $\begin{array}{l}8.7 \mathrm{a} \\
8.1 \mathrm{a} \\
9.3 \mathrm{a} \\
9.5 \mathrm{a} \\
5.7 \mathrm{~b}\end{array}$ & $\begin{array}{l}8.4 a \\
8.8 \mathrm{a} \\
9.2 \mathrm{a} \\
8.4 \mathrm{a} \\
5.9 \mathrm{~b}\end{array}$ \\
\hline $\begin{array}{l}\text { Foothills } \\
\text { Fescue }\end{array}$ & $\begin{array}{l}\text { Very Heavy } \\
\text { Heavy } \\
\text { Moderate } \\
\text { Light } \\
\text { Ungrazed Control }\end{array}$ & $\begin{array}{l}40.8 \mathrm{a} \\
38.2 \mathrm{a} \\
36.4 \mathrm{a} \\
37.8 \mathrm{a} \\
35.2 \mathrm{a}\end{array}$ & $\begin{array}{l}40.3 \mathrm{a} \\
41.1 \mathrm{a} \\
39.8 \mathrm{a} \\
40.9 \mathrm{a} \\
40.8 \mathrm{a}\end{array}$ & $\begin{array}{l}33.9 \mathrm{a} \\
33.3 \mathrm{a} \\
33.2 \mathrm{a} \\
34.2 \mathrm{a} \\
31.9 \mathrm{a}\end{array}$ & $\begin{array}{l}15.4 \mathrm{a} \\
14.3 \mathrm{a} \\
13.2 \mathrm{a} \\
11.5 \mathrm{a} \\
11.3 \mathrm{a}\end{array}$ & $\begin{array}{l}16.3 \mathrm{a} \\
13.1 \mathrm{a} \\
13.3 \mathrm{a} \\
10.7 \mathrm{a} \\
12.8 \mathrm{a}\end{array}$ & $\begin{array}{l}12.8 \mathrm{a} \\
11.2 \mathrm{a} \\
11.3 \mathrm{a} \\
11.3 \mathrm{a} \\
11.5 \mathrm{a}\end{array}$ \\
\hline
\end{tabular}

Within litter and organic matter category means with the same letters are not significantly different $(P<0.05)$.

light autumn grazing.

\section{Foothills Fescue Grassland}

Bare ground increased under moderate, heavy, and very heavy grazing (Table 1). Live vegetative cover was highest under light and moderate grazing, intermediate under heavy and very heavy grazing, and lowest in the control. Litter cover was highest in the control but did not vary among grazed treatments. Standing and fallen litter height decreased with increased grazing intensity (Table 2). Standing litter was 1 to 1.6 times higher in the control than in grazed treatments and fallen litter was 1.6 to 6.7 times higher.

In all litter and organic matter categories, organic carbon was not affected by grazing treatment (Table 3 ). Total organic matter was comprised of approximately two-thirds below ground and one-third above ground components (Fig. 1). Above ground, below ground, and total masses were lower in grazed treatments than in the control. Above ground mass was lower in the very heavy treatment than in other grazed treatments. Root, coarse litter, and fine organic matter masses were not affected by grazing (Fig. 2). Grazing decreased standing litter and live vegetation and increased medium litter. Masses of very fine organic matter were higher in control, heavy, and very heavy treatments than in light and moderate treatments.

\section{Discussion}

\section{Grazing Effects}

As hypothesized, both season and intensity of grazing affected amounts of litter and soil organic matter. Although ecosystem characteristics varied considerably, there were general grazing trends. Bare ground increased while standing and fallen litter, and live vegetative cover and mass decreased with increasing grazing intensity. Early season grazing was more detrimental than late season grazing. Litter depth and height were reduced with treading through breakage and compaction (Naeth et al. 1990). Since sampling occurred late in the growing season, there was little live vegetation. In ungrazed foothills fescue, live cover was low since most vegetation was dormant when sampled, whereas in grazed treatments some autumn forb growth occurred. Also as hypothesized, proportions of different particle-sized litter varied with grazing season and intensity although masses were affected more con-

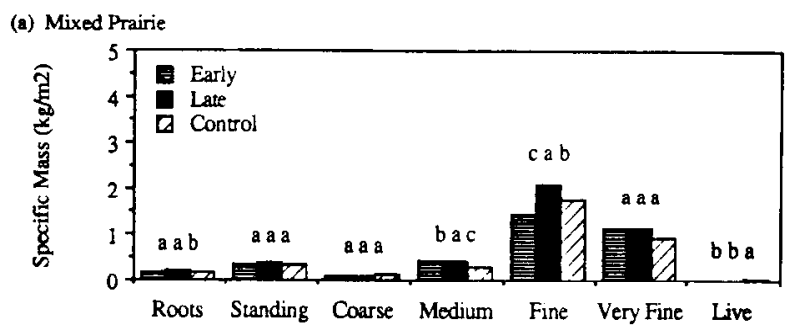

(b) Parkland Fescue

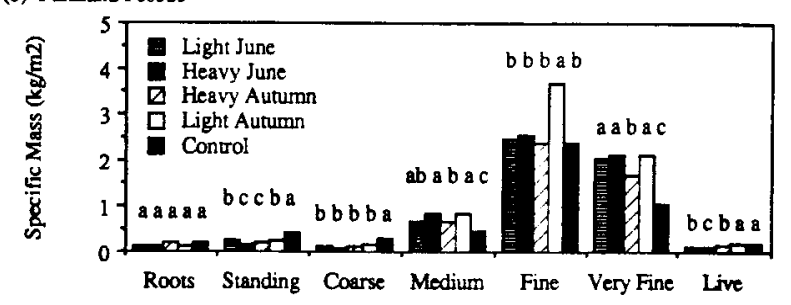

(c) Foothills Fescue

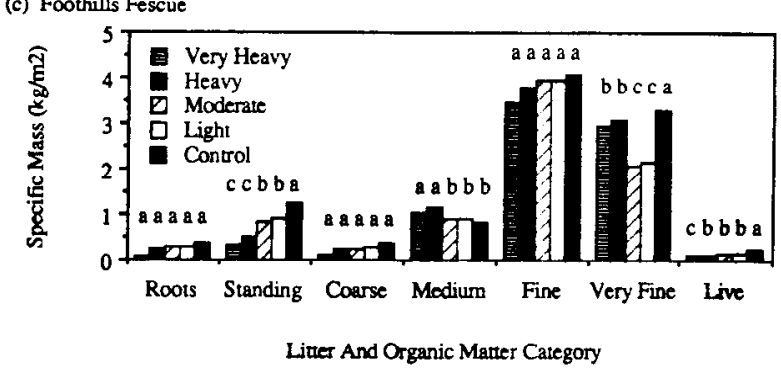

Fig. 2. Specific mass of litter and organic matter categories in (a) mixed prairie, (b) parkland fescue, and (c) foothills fescue grasslands. Within category means with the same letters are not significantly different $(P<0.05)$.

sistently by intensity than season of grazing. All categories except medium litter decreased with increased grazing intensity. With grazing, standing and coarse litter would be trampled, broken into smaller pieces, and thus categorized as medium litter. Soil organic matter levels would reflect changes in total litter.

Early season heavy intensity grazing reduced litter and organic 
matter more than late season heavy intensity grazing or light intensity grazing either late or early in the growing season. Early in the growing season when plant growth is rapid and carbohydrate reserves are low, vegetation is more susceptible to grazing damage. Heavy intensity grazing removes more vegetation with less regrowth and litter accumulation. Data from early season grazing in mixed prairie and heavy June grazing in parkland fescue support this. Foothills fescue treatments also start early in the growing season, but only under heavy intensities did bare ground increase. The late season mixed prairie treatment was heavy, but grazing when plants were dormant reduced the impact. The less negative effects of light intensity and/or late season grazing were supported by higher organic matter masses under late season grazing in mixed prairie, light autumn grazing in parkland fescue, and light or moderate grazing in foothills fescue. Although grazing had not yet occurred at sampling time in autumn treatments in parkland fescue, standing litter was higher under light than heavy grazing intensities.

Plant species changes due to grazing affected amounts and kinds of litter and organic matter. Litter cover in mixed prairie was high for heavy long-term grazing because little club-moss, which comprised an average $58 \%$ of the basal area (Naeth 1985), was dormant when sampled and therefore classed as litter, comprising a major portion of that category. Litter mass similarities between control and grazed treatments were also related to little club-moss in grazed treatments that sorted into coarse and medium litter categories. Reduced litter height under very heavy grazing compared to heavy grazing in foothills fescue was due to reduction or elimination of taller plant species under very heavy grazing and replacement by lower growing grasses and forbs. These shallow rooted species in heavier grazed treatments (Johnston 1962), rooting in the upper $20 \mathrm{~cm}$ of the soil profile (Coupland 1979), can account for higher values in organic matter categories that included small roots.

Grazing can affect litter decomposition rate, which affects organic matter mass. Trampling can reduce litter particle size and create better litter-soil contact, facilitating more rapid decomposition by soil microorganisms (McCalla 1943, Dyksterhuis and Schmutz 1947) in some grazed treatments than in controls. This is evidenced by lower below ground and total organic matter masses in the controls than in the light autumn treatment in parkland fescue and the late season treatment in mixed prairie, and higher very fine masses in very heavy and heavy treatments than in light and moderate treatments in foothills fescue. In mixed prairie, forbs and shrubs were more prominent under early season grazing and grasses more prominent under late season grazing (Naeth 1985). Grasses contain less lignin than shrubs and forbs and decompose more rapidly (Norman 1933), increasing fine organic matter under late season grazing.

Reduced standing litter with long-term grazing was in agreement with most North American grassland studies (Coupland 1979). Litter masses were higher than those for other Alberta mixed prairie studies (Smoliak 1965, Smoliak et al. 1972, Willms et al. 1986); it is not known whether little club-moss was included in litter samples for these studies. Standing and coarse litter values were similar to those of Coupland (1973) for Saskatchewan mixed prairie but coarse, fine, and very fine values are not comparable to those in this study due to differences in sieve size and sampling depth. Rough fescue above ground litter values were higher than others from Alberta (Smoliak et al. 1985, Willms et al. 1986, Bailey et al. 1987), again due to sampling differences. Crider (1955) reported partial or complete defoliation reduces plant root mass. Although mass of roots greater than $0.2 \mathrm{~mm}$ was not affected by grazing in this study, there were treatment differences in fine and/or very fine organic matter masses which comprised smaller roots.

\section{Organic Carbon}

Higher organic carbon in roots, standing litter, and coarse litter compared to medium litter, fine and very fine organic matter reflected the larger ratio of mineral soil to plant material in the latter categories. Organic carbon in litter of different particle sizes may be affected by $\mathrm{CO}_{2}$ losses during decomposition. For fescue and spear grass species, 28 to $33 \%$ of the original carbon in roots and residue may be lost within 47 weeks of incubation (Herman 1974). Plant species differ in chemical composition and significant differences in dominant species within grazing treatments may affect total carbon in the organic matter. Results from this study are in agreement with those of Dormaar et al. (1977), who reported total carbon does not change with grazing intensity. Dormaar et al. (1984) also found higher amounts of total carbon in a heavy grazed site compared to an ungrazed one in mixed prairie at Manyberries, Alberta. Large amounts of little club-moss may have contributed to these higher values.

\section{Management Implications}

The increases in bare ground in mixed prairie and parkland fescue under grazing are of little practical significance because both $\%$ bare ground and the increases were so small. However the increases in foothills fescue under heavy and very heavy grazing are of practical significance since hydrologic changes such as reduced infiltration and increased runoff occur in this ecosystem when bare ground is approximately $15 \%$ (Johnston 1962, Naeth 1988).

Naeth et al. (1991) found the amount of large particle-sized relative to small particle-sized litter and organic matter was a critical factor in determining magnitude of water holding capacity (WHC) of litter and the soil surface in a given rangeland. They found WHC increased with increasing particle-size, being higher for roots and standing and fallen litter than for soil organic matter categories. WHC decreased with heavy intensity early season grazing through species composition changes and trampling. Thus, grazing regimes facilitating accumulation of litter in larger particlesized categories would increase overall hydrologic condition. For example, although the heavy and very heavy treatments in foothills fescue have high fine and very fine organic matter, there were significant reductions in the high WHC categories such as standing litter, coarse litter, and roots. Thus these treatments would have an overall lower hydrologic condition than the light and moderate treatments in that ecosystem.

When considering the importance of a good ground cover and litter accumulation, several management implications are evident. For heavy intensity grazing in mixed prairie, late season grazing after July is better than early season grazing. For grazing during the growing season, a moderate intensity is advised. In parkland fescue grassland, reducing June or early season grazing in favor of autumn grazing would maintain the most litter and organic matter. Grazing foothills fescue grasslands at a moderate or light seasonlong regime appears to be best and may be an alternative to rotational or deferred grazing which is often economically difficult on large foothills ranches. Certainly from a hydrologic perspective, the above grazing regimes are the best for maintaining critical levels of litter and organic matter for good hydrologic condition (Naeth 1988).

\section{Conclusions}

Both season and intensity of grazing affected amounts of litter and soil organic matter, with heavy intensity and/or early season grazing having a greater negative effect than light intensity and/or late season grazing. Bare ground increased while standing and fallen litter, and live vegetative cover and mass decreased with 
increasing grazing intensity. Bare ground values were only practically significant in the foothills fescue grassland where they were high enough to affect hydrologic condition.

Proportions of different particle-sized litter varied with grazing season and intensity. Litter masses were affected more consistently by intensity than season of grazing, with heavy intensity and/or early season regimes having the greatest negative effect. All categories except medium litter decreased with increased grazing intensity. Higher litter and organic matter in grazed treatments than in controls in some medium and small particle-sized categories was probably due to more rapid decomposition when vegetation was trampled and broken down into smaller particle sizes. More larger particle-sized organic matter in controls than grazed treatments was due to lack of treading and removal by grazing.

\section{References}

Bailey, A.W., M.G. Willoughby, and B.D. Irving. 1987. Effect of grazing on forage and beef production from rough fescue rangeland in central Alberta. Farming for the Future Final Report. Proj. 84-0335.

Black, C.A. 1965. Methods of soil analysis. Part 1: Physical and mineralogical properties, including statistics of measurement and sampling. Agronomy Ser. 9. Amer. Soc. Agron.

Branson, F.A. 1984. Evaluation of "Impacts of grazing intensity and specialized grazing systems on watershed characteristics and responses". pp. 985-1000. In: Developing strategies for rangeland management. NRC/NAS. Westview Press/Boulder and London.

Canada Department of Agriculture. 1979. Glossary of terms in soil science. Can. Dep. Agr. Pub. 1459.

Coupland, R.T. 1973. I. Dynamics of aboveground standing crop. Tech. Report 27. Canadian Comm. for the Internat. Biol. Prog. Saskatoon, Sask.

Coupland, R.T. 1979. Grassland ecosystems of the world: analysis of grasslands and their uses. Cambridge Univ. Press. Cambridge, Engl. IBP 18.

Coupland, R.T., N.A. Skoglund, and A.J. Heard. 1960. Effects of grazing in the Canadian mixed prairie. Proc. Eighth Internat. Grassl. Congr. pp. 212-215.

Crider, F.J. 1955. Root growth stoppage resulting from defoliation of grass. Tech. Bull. USDA No. 1102:2-23.

Dormaar, J.F., A. Johnston, and S. Smoliak. 1977. Seasonal variations in chemical characteristics of soil organic matter of grazed and ungrazed mixed prairie and fescue grassland. J. Range Manage. 30:195-198.

Dormaar, J.F., A. Johnston, and S. Smoliak. 1984. Seasonal changes in carbon content, dehydrogenase, phosphatase, and urease activities in mixed prairie and fescue grassland Ah horizons. J. Range Manage. 37:31-37.

Dyksterhuis, E.J., and L.M. Schmutz. 1947. Natural mulches or 'litter' of grassland with kinds and amounts on a southern prairie. Ecology 28:163-179.

Herman, W.A. 1974. Chemical composition of roots and decomposing root residues from three grass species. M.Sc. Thesis. Dept. Soil Sci. Univ. Alberta, Edmonton.

Howitt, R.W. 1988. Soil survey of the County of Beaver. Alberta Soil Survey Report 47. Alberta Res. Counc. Open File Report 1987-4.

Johnston, A. 1961. Comparison of lightly grazed and ungrazed range in fescue grassland of southwestern Alberta. Can. J. Plant Sci. 41:615-622.
Johnston, A. 1962. Effects of grazing intensity and cover on the waterintake rate of fescue grassland. J. Range Manage. 15:79-87.

Johnston, A., J.F. Dormaar, and S. Smoliak. 1971. Long-term grazing effects on fescue grassland soils. J. Range Manage. 24:185-188.

Kjearsgaard, A.A., T.W. Peters, and W.W. Pettapiece. 1982. Soil survey of the County of Newell No. 4, Alberta. Alberta Institute of Pedology Report S-82-41.

Lodge, R.W. 1954. Effects of grazing on the soils and forage of mixed prairie in southwestern Saskatchewan. J. Range Manage. 7:166-170.

McCalla, T.M. 1943. Microbiological studies of the effect of straw used as a mulch. Trans. Kansas Acad. Sci. 43:52-56.

Meeuwig, R.0. 1970. Infiltration and soil erosion as influenced by vegetation and soil in northern Utah. J. Range Manage. 23:183-188.

Naeth, M.A. 1985. Ecosystem reconstruction and stabilization following pipeline construction through solonetzic native rangeland in southern Alberta. M.Sc. Thesis. Univ. Alberta. Edmonton.

Naeth, M.A. 1988. The impact of grazing on litter and hydrology in mixed prairie and fescue grassland ecosystems of Alberta. Ph.D. Thesis. Univ. Alberta. Edmonton.

Naeth, M.A., D.J. Pluth, D.S. Chanasyk, A.W. Bailey, and A.W. Fedkenheuer. 1990. Soil compacting impacts of grazing in mixed prairie and fescue grassland ecosystems of Alberta. Can. J. Soil Sci. 70:157-167.

Naeth, M.A., A.W. Bailey, D.S. Chanasyk, and D.J. Pluth. 1991. Water holding capacity of litter and soil organic matter in mixed prairie and fescue grassland ecosystems of Alberta. J. Range Manage. 44:13-17.

Norman, A.G. 1933. The natural decomposition of plant materials. Sci. Prog. 27:470-485.

Pavlick, L.E., and J. Looman. 1984. Taxonomy and nomenclature of rough fescues, Festuca altaica, Festuca campestris ( $F$. Scabrella var. major), and Festuca hallii, in Canada and the adjacent part of the United States. Can. J. Bot. 62:1739-1749.

Risser, P.G. 1984. Methods for inventory and monitoring of vegetation, litter, and soil surface condition. pp. 647-690. In: Developing strategies for range management. NRC/NAS. Western Press/Boulder and London.

Shapiro, S.S., and M.B. Wilk. 1965. An analysis of variance test for normality (complete samples). Biometrika 52:591-611.

Sinton, H.M.M. 1980. Effect of burning and mowing on Festuca hallii (Vasey) Piper, Festuca scabrella Torr. M.Sc. Thesis. Dept. Plant Sci., Univ. Alberta. Edmonton.

Smoliak, S. 1965. A comparison of ungrazed and lightly grazed StipaBouteloua prairie in southeastern Alberta. Can. J. Plant Sci. 45:270-275.

Smoliak, S., J.F. Dormaar, and A. Johnston. 1972. Long-term grazing effects on Stipa-Bouteloua prairie soils. J. Range Manage. 25:246-250.

Smoliak, S., B.W. Adams, B.G. Schuler, R.A. Wroe, S.G. Klumph, and W.D. Willms. 1985. Forage production on selected native prairie sites in southern Alberta. Res. Branch, Agr. Can. Lethbridge Res. Sta. Cont. 5.

Steel, R.G.D., and J.H. Torrie. 1980. Principles and procedures of statistics: a biometrical approach. 2nd ed. McGraw-Hill, New York.

Tomanek, G.W. 1969. Dynamics of mulch layer in grassland ecosystems. In: Dix, R.L. and Beidleman, R.G. (eds.). The grassland ecosystem, a preliminary synthesis. Range Sci. Dep. Scrics No. 2:225-240. Colorado State Univ. Fort Collins.

Willms, W.D., S. Smoliak, and A.W. Bailey. 1986. Herbage production following litter removal on Alberta native grasslands. J. Range Manage. 39:536-540. 